Каменський А. Зарубіжний досвіА стандартизації професійної освіти

УДК 377/378:006(1-87)

DOI https://doi.org/10.24919/2308-4863.1/26.195855

\author{
Андрій КАЛЕНСЬКИЙ, \\ orcid.org/0000-0001-9034-5042 \\ доктор педагогічних наук, доцент, \\ завідувач лабораторії науково-методичного супроводу \\ підготовки фахівців у коледжах і технікумах \\ Інституту професійно-технічної освіти \\ Національної академї педагогічних наук Украӥни \\ (Киї, Україна) kalenskyandrii@gmail.com
}

\title{
ЗАРУБІЖНИЙ ДОСВІД СТАНДАРТИЗАЦІЇ ПРОФЕСІЙНОЇ ОСВІТИ
}

На основі результатів аналізу педагогічної літератури, нормативних актів у галузі зарубіжного досвіду стандартизації професійної освіти визначено, щзо є чотири моделі інституційного регулювання системи кваліфікацій: державне центтралізоване регулювання; корпоративне регулювання, щзо базується на багатосторонньому соиіальному діалозі та незалежних агентствах; децентралізоване мінімальне регулювання, шо базується на самостійності різноманітних учасників та їхній ініціативі і відповідальності і властиве країнам з ліберальним устроєм ринкової економіки і трудових відносин; регулювання, щзо базується на стратегічній співпраці між урядовими інституціями і роботодавцями, спрямоване на досягнення цілей швидкого економічного розвитку певних галузей або начіональної економіки.

Незважаючи на різні моделі стандартизачії професійної освіти в краӥнах, Свропейський Союз визначає стратегї розвитку освіти та ї̈ направленість на інновачійну модернізачію. Відповідно до визначення Європейської рамки кваліфікацій кваліфікація - цее «формальний результат процесу оцінки й офіційного визнання результатів навчання, щуо отримується в разі, коли компетентний орган вважає, щзо особа досягла результатів навчання, котрі відповідають установленим стандартам». Кваліфікаџія підтверджується офіційними документами, такими як диплом, атестат або свідоцтво про присвоєння кваліфікаиії. В основі лежать норми та вимоги, щзо регулюють присудження кваліфікації. Норми - иее кваліфікаџійні стандарти: професійні стандарти описують вимоги до працівників; освітні стандарти, які можуть визначати передбачуваний результат прочесу навчання; кваліфікаційні стандарти, щзо можуть описувати предмет оцінки, критерії виконання, методи оцінки, склад комісії, щзо має право на присвоєння кваліфікації.

Ключові слова: професійний стандарт, освітній стандарт, державне иентралізоване регулювання, корпоративне регулювання, децеентралізоване регулювання, регулювання на стратегічній співпраці.

\author{
Andrii KALENSKYI, \\ orcid.org/0000-0001-9034-5042 \\ Doctor of Pedagogical Sciences, Associate Professor, \\ Head of the Laboratory of Scientific and Methodological Support \\ Training Experts in Universities and Colleges \\ of the Institute of Vocational Education and Training \\ of the National Academy of Pedagogical Sciences of Ukraine \\ (Kyiv, Ukraine)kalenskyandrii@gmail.com
}

\section{FOREIGN EXPERIENCE OF PROFESSIONAL EDUCATION STANDARDIZATION}

Based on the results of pedagogical literature analysis, normative acts in the field of foreign experience standardization vocational education it is determined that there are four models qualification system of institutional regulation: state centralized regulation, which is peculiar to the countries of Western, Southern and Eastern Europe; corporate regulation, based on multilateral social dialogue and independent agencies, which is inherent in English-speaking countries with a liberal market economy and labor relations; decentralized minimum regulation based on the independence of the various actors and their initiative and responsibility; regulation based on strategic cooperation between governmental institutions and employers, aimed at achieving the rapid economic development goals of certain sectors or the national economy, typical of so-called developing economies.

Despite different standardization models of vocational education in countries, the European Union defines strategies for the development of education and its focus on innovative modernization. According to the definition European Qualifications Framework, a qualification is a "formal the process result of assessment and formal recognition of learning outcomes, obtained when the competent authority considers that a person has achieved training results that meet the set standards". Qualification is supported by official documents such as diploma, certificate or certificate of qualification. The basis is the rules and requirements governing the award of qualifications. Standards are qualification standards: 
professional standards describe the requirements for employees; educational standards that can determine the intended outcome of the learning process; qualification standards that can describe the subject of assessment, performance criteria, methods of assessment, composition of the commission that has the right to qualify.

Key words: professional standard, educational standard, centralized state regulation, corporate regulation, decentralized regulation, regulation on strategic cooperation.

Постановка проблеми. Якість професійної освіти - це відповідність освітнього процесу, умов, в яких він відбувається, та результатів навчання вимогам законодавства та освітнім, професійним чи міжнародним стандартам. Аналіз досвіду стандартизації професійної освіти в країнах з високорозвинутою економікою полегшить пошук шляхів з визначення і встановлення норм, правил та вимог до реалізації освітнього процесу, його результатів.

Аналіз досліджень. До досвіду стандартизації професійної освіти в країнах з високорозвинутою економікою звертались у своїх роботах Н. Дупак, В. Луговий, М. Ісабеков, Л. Короткова, Г. Лук'яненко, Л. Лук'янова, С. Мельник, І. Савченко, Т. Славнова, Ж. Таланова, О. Туманова та багато інших вітчизняних та зарубіжних учених. Цікаве дослідження із стандартизації в системі професійної освіти і навчання Великої Британії провела С. Леу. Спираючись на їхні праці та нормативні документи, розглянемо основні типові сценарії правового та інституційного регулювання стандартизації професійної освіти.

Мета статті - здійснити аналіз досвіду стандартизації професійної освіти в країнах з високорозвинутою економікою.

Виклад основного матеріалу. В. Луговий, Ж. Таланова (Луговий, Таланова, 2017: 8) зазначають, що у світовій практиці розрізняють так звану професійну освіту та підготовку (англ. VET - Vocational Educational and Training) та вищу освіту (англ. HE - Higher Education). А у вищій освіті виокремлюють сектори університетської і неуніверситетської (прикладної) вищої освіти, тобто професійна освіта в таких країнах може бути вищою (HE) і невищою (VET), тому будемо розглядати досвід стандартизації освіти в цих країнах без їі поділу на вищу та невищу.

У деяких країнах використовується поняття професійного стандарту (occupational standard) нормативного документа, який відображає мінімально необхідні вимоги до професії за кваліфікаційними рівнями та професійних компетенцій 3 урахуванням забезпечення якості, продуктивності й безпеки виконуваних робіт.

Потрібно зазначити, що в англійській мові $\epsilon$ відмінність у термінології: поряд із "оccupational standard" використовується термін "professional standard". Останнє вживається, наприклад, у
Великобританії не для позначення виду занять (occupational), а саме для професій (professional), які потребують спеціалізованої вищої професійної освіти і ліцензії для допуску до професії. Крім цього, використовується термін "qualification standard" як перелік типово очікуваних умінь, досягнень і здібностей, пов'язаних із кваліфікаціями одного рівня Національної рамки кваліфікації.

Зважаючи на розвиток систем кваліфікацій, можна виділити чотири типові моделі правового та інституційного регулювання системи кваліфікацій. У літературі та різних документах часто виокремлюють такі типові моделі (Каленський та ін., 2018: 65):

1. Державне централізоване регулювання, яке різною мірою властиве країнам Західної, Південної, а також Східної Свропи.

У Франції і Бельгії, наприклад, $є$ два типи професійних стандартів, а саме: ті, які описують трудову діяльність, що підлягає виконанню здобувачем кваліфікації (стандарт діяльності - référentiel d'activité), i ті, які розробляються і використовуються у сфері праці та зайнятості (стандарти професій - referentiel metier) і включені до так званого Переліку професій і занять (Répertoire Opérationnel des Métiers et des Emplois). Структури та організації, що присуджують кваліфікаціï, розробляють стандарти діяльності (référentiel d'activité), які співвідносяться з одним або декількома стандартами професій (référentiel métier).

2. Корпоративне регулювання, що базується на багатосторонньому соціальному діалозі та незалежних агентствах і різною мірою властиве Німеччині, Австрії, Данії, Нідерландам, Швейцарії.

Серед особливостей національних стандартів професійної освіти Німеччини виокремимо такі (Короткова та ін, 2011: 186):

- повний перелік комплексів документації за окремими групами професій (інструкцій про структуру професій, каталогів професій, їх опис, навчальні плани та програми, механізм оцінювання якості);

- оцінювання якості процесу і результату професійної освіти здійснюється торгово-промисловими палатами;

- професійна освіта максимально наближена не тільки до потреб німецької економіки, а й тісно пов'язана з їі традиціями; 
- диференціація професійної підготовки дає змогу оптимально врахувати динаміку потреб роботодавців та можливість експериментально перевірити інноваційні підходи до підготовки фахівців;

- модернізація форм і методів професійного навчання грунтується на широкому використанні інформаційних технологій навчання;

- розширення профілю професійної підготовки здійснюється шляхом включення у кваліфікацію робітника особистісного потенціалу, що сприяє їхньому духовному й інтелектуальному розвиткові.

3. Децентралізоване мінімальне регулювання (США, Великобританія). Воно базується на самостійності різноманітних учасників та їхній ініціативі і відповідальності і властиве країнам з ліберальним устроєм ринкової економіки і трудових відносин.

У Великобританії (Леу, 2018: 9) професійні стандарти $\epsilon$ :

- національними, позаяк призначені та придатні для використання на всій території Великобританії;

- професійними, оскільки описують продуктивність, необхідну для виконання певних функцій на робочому місці, тобто підтверджують ефективність професійної діяльності, що встановлена й погоджена репрезентативною групою роботодавців та інших зацікавлених сторін.

Вони затверджуються Радою 3 питань національних стандартів Великої Британії. Національний професійний стандарт визначає знання, уміння та компетентності, що необхідні для виконання визначеної роботи в межах заданої профеciï, які особа демонструє на робочому місці. Національні професійні стандарти розробляють саме роботодавці за сприянням відповідних Ради галузевих умінь та Організації з питань визначення стандартів.

Стандарти учнівства $\epsilon$ комплексом стандартів: професійного стандарту, освітнього стандарту та стандарту оцінювання.

Свідоцтво, сертифікат, диплом (Леу, 2018: 7) видається залежно від кількості опанованих кредитів та рівня складності, відповідно до рівня рамки кваліфікацій. Усі кваліфікації професійної освіти можна набути в освітніх закладах різного типу. Координація здійснюється Управлінням 3 питань кваліфікацій та іспитів для Англії, Уельсу й Північної Ірландії та Шотландською агенцією кваліфікацій та іншими урядовими підрозділами.

4. Регулювання, що базується на стратегічній співпраці між урядовими інституціями і робото- давцями, спрямоване на досягнення цілей швидкого економічного розвитку певних галузей або національної економіки, властиве таким країнам як Сінгапур, Південна Корея, Японія.

Особливостями національних стандартів професійної освіти Японії є (Сакун, 2004): уніфікація освітніх програм незалежно від відомчої чи галузевої підпорядкованості освітнього закладу; розширення профілю підготовки майбутніх фахівців; відповідність професійної освіти встановленим вимогам і нормам; введення мінімальних типових правил та типових освітніх програм підготовки майбутніх фахівців; проведення кваліфікаційних випробувань (іспитів) спеціальними асоціаціями; координація в межах своєї компетенції професійної освіти з боку Міністерства освіти і Міністерства праці; введення освітніх програм з великою загальноосвітньою спрямованістю Міністерством освіти.

Незважаючи на різні моделі стандартизації професійної освіти в країнах, Європейський Союз визначає стратегії розвитку освіти та ії направленість на інноваційну модернізацію.

Стратегію розвитку всього суспільства $\mathrm{EC}$ в цілому й окремих iï країн розробляли й планували Інноваційний Союз (IU), Європейський інститут інновацій і технологій (ЕIT), Постійний Комітет 3 вищої освіти і наукових досліджень (HERSC).

Європейська Комісія 30. 11. 2011 р. прийняла від вищеназваних розробників «План стратегічних інновацій на 2014-2020 pp.», а також Генеральний план «Стратегія Європи - 2020», в яких визначає стратегію розвитку освіти в $\mathrm{CC}$ і країнах суміжних територій.

Основним завданням модернізації професійної освіти Європейського Союзу $є$ створення бази нормативних документів ECVET, EQAVET, EQAR, EQF: ECVET (European credit education technique) Європейська кредитна система для професійно-технічної освіти; EQAVET (The European model of quality assurance in VET) - Свропейська модель забезпечення якості в системі ПТО.

Для забезпечення якості професійної освіти були розроблені Європейські єдині критерії контролю їі якості; EQAR (European Register of Quality Assurance (for higher education) - Свропейський реєстр забезпечення якості (для вищої освіти); EQF (European Framework of Qualifications) Європейська рамкова структура кваліфікацій.

Спільна система забезпечення якості (CQAF) $\epsilon$ європейським механізмом для забезпечення та підвищення якості професійної освіти та професійного навчання (ПТО), що спирається на осно- 
вні принципи найбільш відповідних наявних моделей забезпечення якості.

CQAF включає в себе: планування, здійснення та оцінку й аналіз системи безперервної професійної освіти країнами-учасниками; методику iii оцінки (як самооцінки, так і зовнішньої); систему моніторингу та інструменти вимірювання для його проведення.

Відповідно до визначення Свропейської рамки кваліфікацій кваліфікація - це «формальний результат процесу оцінки й офіційного визнання результатів навчання, що отримується в разі, коли компетентний орган вважає, що особа досягла результатів навчання, котрі відповідають установленим стандартам».

Кваліфікація підтверджується офіційними документами (диплом, атестат свідоцтво тощо) про присвоєння кваліфікації. В основі лежать норми та вимоги, що регулюють присудження кваліфікації. Норми - це кваліфікаційні стандарти:

а) професійні стандарти описують вимоги до працівників, «основні трудові функції, що виконуються людьми», завдання та професійну діяльність, а також типові компетентності для такої професії;

б) освітні стандарти, які можуть визначати передбачуваний результат процесу навчання (опанування компетентностей, типових для такої професіі), що приводить до присудження кваліфікації, навчальної програми в термінах змісту, цілей навчання та навчального плану, а також методів навчання та організації навчання, наприклад, навчання на базі підприємства або на базі школи.
Освітні стандарти відповідають на запитання: «Що потрібно знати і уміти учням, щоб ефективно працювати?»;

в) кваліфікаційні стандарти, що можуть описувати предмет та методи оцінки, критерії оцінювання, склад комісії, що має право на присвоєння кваліфікації. Вони відповідають на запитання: «Як дізнатися, що учень завершив навчання, оволодів компетентностями та здатний працювати?».

Висновки. Зарубіжний досвід дає змогу розглядати стандартизацію професійної освіти як діяльність 3 визначення і встановлення норм, правил та вимог щодо реалізації освітнього процесу, результатів цієї освіти і відповідних кваліфікацій, незалежно від форм та шляхів їх опанування (формальний, неформальний, інформальний). Визначено чотири моделі інституційного регулювання системи кваліфікацій: державне централізоване регулювання; корпоративне регулювання, що базується на багатосторонньому соціальному діалозі та незалежних агентствах; децентралізоване мінімальне регулювання, що базується на самостійності різноманітних учасників та їхній ініціативі і відповідальності і властиве країнам 3 ліберальним устроєм ринкової економіки і трудових відносин та регулювання, що базується на стратегічній співпраці між урядовими інституціями і роботодавцями. У вітчизняній практиці стандартизації необхідно зазначити, що розроблення освітніх стандартів має здійснюватися на основі професійних стандартів, а якість підготовки фахівців визначатися кваліфікаційними стандартами (стандартами якості).

\section{СПИСОК ВИКОРИСТАНИХ ДЖЕРЕЛ}

1. Дупак Н. В. Стандартизація в галузі освіти як комплексна проблема. Вісн. Житомир. держ. ун-ту ім. I. Франка. 2010. № 52. С. 53-57.

2. Каленський А. А., Лузан П. Г., Ваніна Н. М., Пащенко Т. М., Кравець С. Г., Пятничук Т. В. / за наук. ред. А. А. Каленського. Стандартизація професійної освіти: теорія і практика : монографія. Житомир: «Полісся», 2018. $256 \mathrm{c}$.

3. Короткова Л. І., Лук’яненко Г. І., Лук’янова Л. Б., Мельник С. В., Савченко І. М. Професійні стандарти: теорія і практика розроблення : колективна монографія. Київ : НАПН України, 2011. 313 с.

4. Леу С. О. Особливості стандартизації в системі професійної освіти і навчання Великої Британії : методичні рекомендації. Київ : Компринт, 2018. 55 с.

5. Луговий В. І., Таланова Ж. В. Особливості стандартизації професійної невищої освіти : теоретико-методологічний аспект. Педагогіка і психологія. Вісн. НАПН України. № 1 (94). 2017. С. 5-21.

6. Сакун Л. В. Теорія і практика підготовки фахівців сфери туризму в розвинутих країнах світу : монографія. Київ : «МАУП». 2004. URL: http://infotour.in.ua/sakun13.htm. 
Каменський А. Заруьіжний досвіА стандартизації професійної освіти

REFERENCES
1. Dupak, N. V. (2010). Standartyzatsiia v haluzi osvity yak kompleksna problema. [Standardization in education as a
complex problem] Visn. Zhytomyr. derzh. un-tu im. I. Franka. 52. S. 53-57 [in Ukrainian].
2. Kalenskyi, A. A., Luzan, P. H., Vanina, N. M., Pashchenko, T. M., Kravets, S. H., Piatnychuk, T. V. (2018). Standar-
tyzatsiia profesiinoi osvity: teoriia i praktyka; monohrafiia / za nak. red. A. A. Kalenskoho. [Standardization of Vocational
Education: Theory and Practice : monograph]. Zhytomyr: „Polissia”, 256 s. [in Ukrainian].
3. Korotkova, L. I., Lukianenko, H. I., Lukianova, L. B., Melnyk, S. V., Savchenko, I. M. (2011). Profesiini standarty :
teoriia i praktyka rozroblennia; kolektyvna monohrafiia. [Professional standards: theory and practice of development: collec-
tive monograph]. Kyiv : NAPN Ukrainy, 313 s. [in Ukrainian].
4. Leu, S. O. (2018). Osoblyvosti standartyzatsii v systemi profesiinoi osvity i navchannia Velykoi Brytanii: metod.
rek. [Features of standardization in the UK vocational education and training system: guidelines]. Kyiv: Komprynt. 55 s.
[in Ukrainian].
5. Luhovyi. V. I., Talanova. Zh. V. (2017). Osoblyvosti standartyzatsii profesiinoi nevyshchoi osvity; teoretyko-metod-
olohichnyi aspekt. [Features of standardization of professional lower education; theoretical and methodological aspect].
Pedahohika i psykholohiia. Visn. NAPN Ukrainy. 1 (94). S. 5-21 [in Ukrainian].
6. Sakun, L. V. (2004). Teoriia i praktyka pidhotovky fakhivtsiv sfery turyzmu v rozvynutykh krainakh svitu: monohrafiia.
[Theory and practice of training tourism professionals in developed countries: monograph]. Kyiv: “MAUP”. Retrieved from:
http://infotour.in.ua/sakun13.htm.
http://infotour.in.ua/sakun13.htm. 